\title{
Bio-Accessibility and Health Risk Assessment of Heavy Metals in Indoor Dust From Higher Institutions in Ondo State, Nigeria
}

Omoyemi Oluwatosin Ajayi ( $\sim$ Duroyem96@gmail.com)

Federal University of Technology Akure School of Sciences https://orcid.org/0000-0002-6735-2559

Abdullahi Tunde Aborode

University of llorin

Joshua Iseoluwa Orege

Dalian Institute of Chemical Physics

Tolulope Oyelekan Oyewumi

Federal University of Technology Akure

Amina Othmani

University of Monastir: Universite de Monastir

Mary Adeola Adegbola

Department of Zoology and Environmental Biology, Ekiti State University, Ado-Ekiti, Nigeria

Odunola Blessing Orege

University of Ibadan

\section{Research Article}

Keywords: Indoor Dust, Heavy Metals, Health Risk, Exposure Pathway, Tertiary Institution, Ondo State

Posted Date: June 10th, 2021

DOl: https://doi.org/10.21203/rs.3.rs-479774/v1

License: (9) This work is licensed under a Creative Commons Attribution 4.0 International License.

Read Full License 

INDOOR DUST FROM HIGHER INSTITUTIONS IN ONDO STATE, NIGERIA

${ }^{1}$ Omoyemi Oluwatosin Ajayi; ${ }^{2}$ Abdullahi Tunde Aborode; ${ }^{3,4}$ Joshua Iseoluwa Orege; ${ }^{1}$ Tolulope

Oyelekan Oyewumi; ${ }^{5}$ Amina Othmani; ${ }^{6}$ Adeola Mary Adegbola, ${ }^{7}$ Odunola Blessing Orege

6

${ }^{1}$ Department of Chemistry, Federal University of Technology, Akure, Nigeria

$8 \quad{ }^{2}$ Department of Chemistry, University of Ilorin, Ilorin, Nigeria

${ }^{3}$ Dalian Institute of Chemical Physics, Chinese Academy of Sciences, Dalian, 116023, China

${ }^{4}$ Department of Industrial Chemistry, Ekiti State University,PMB 5363, Ado Ekiti Nigeria;

${ }^{5}$ Faculty of sciences of Monastir, University of Monastri, Avenue of the Environment, 5019

Monastir, Tunisia

${ }^{6}$ Department of Zoology and Environmental Biology, Ekiti State University, PMB 5363, Ado

Ekiti Nigeria

${ }^{7}$ Department of Chemistry, University of Ibadan, Ibadan, Oyo State, Nigeria

Correspondence: ${ }^{1}$ Omoyemi Oluwatosin Ajayi (Duroyem96@ gmail.com)

${ }^{3,4}$ Joshua Iseoluwa Orege (joshua.orege@dicp.ac.cn)

Other Authors Email Contacts: ambassadorabdullah0@gmail.com

oyewumitolulope2@gmail.com

othmaniamina@gmail.com

adegbolamaryadeola@gmail.com

omitolaodunola@gmail.com 


\section{Abstract}

Quality of indoor air has been a major concern over time particularly in urban areas. Amidst the indoor air parameters, particulate matter/dust is of core interest owing to the fact that it acts as sediment for metals and other pollutants. Considering the ample amount of time spent indoor by students, this study has been mapped out to investigate the quality of air in tertiary institutions in Ondo State, Nigeria based on their proximity to more anthropogenic activities. Herein, $\mathrm{pH}$, conductivity, and anion concentrations in the indoor dust samples were estimated employing standard analytical methods. Our findings revealed a sequence of anion concentration level as follows, $\mathrm{Cl}^{-}>\mathrm{SO}_{4}{ }^{2-}>\mathrm{NO}_{3}{ }^{-}$. Also, the concentrations of some selected metals were analyzed using flame atomic absorption spectrophotometer (FAAS). The variation in metal concentration observed in most study sites was in the order $\mathrm{Cu}>\mathrm{Zn}>\mathrm{Cr}>\mathrm{Pb}>\mathrm{Cd}$. The mean heavy metal variation followed the trend based on the sample collection sites considered in the present study with $\mathrm{FE}>\mathrm{OA}>\mathrm{FU}>\mathrm{HT}$ and $\mathrm{Cu}(0.480 \mathrm{mg} / \mathrm{kg}), \mathrm{Zn} \quad(0.409 \mathrm{mg} / \mathrm{kg}), \quad \mathrm{Cr} \quad(0.407 \mathrm{mg} / \mathrm{kg}), \mathrm{Pb}$ $(0.149 \mathrm{mg} / \mathrm{kg})$ and $\mathrm{Cd}(0.029 \mathrm{mg} / \mathrm{kg})$ being the highest concentration of each of the metals. However, all the metal concentrations were below the permissible level. The result from noncarcinogenic study indicates that the average daily dose (by ingestion) was found to be the core exposure pathway such that ADDing> ADDderm> ADDinh. Nevertheless, the hazard quotient (HQ) and hazard index (HI) were less than 1. This implies that no potential health risk. More generally, a relative degree of safety and strict regulations is suggested to be put in place to maintain the status.

Keywords: Indoor Dust, Heavy Metals, Health Risk, Exposure Pathway, Tertiary Institution, Ondo State

\section{Abbreviation}

FU: Federal University of Technology Akure (FUTA); FE: Federal College of Agriculture (FECA); HT: Ondo State College of Health Science Technology (OSCOHST), Akure; OA: Adeyemi College of Education (ACE); ADDing: average daily dose via ingestion; ADDinh: average daily dose via inhalation; ADDderm: average daily dose via dermal contact Introduction 
Air quality is a major concern with respect to the fast growing population and unprecedented rise

62 in urbanization, technological advancement and industrial activities (Wu et al. 2015; Zhang et al. 2015. The physiochemical compositions of air are altered by organic compounds such as polyaromatic hydrocarbons (PAHs) (Wang et al. 2010), airborne particulate matter (Saeedi et al.

65 2012; Keshavarzi et al. 2015), inorganic compounds such as heavy metals among others (Li et al. 2017).

Indoor dust is a heterogeneous mixture of inorganic and organic particles that varies in size and shape and may penetrate easily into lungs and bloodstreams (Zheng et al. 2017). Generally, the concentration of heavy metals in background soil of any area is usually lower than that in airborne dust as a result of several factors which may include surface area of the later, agglomeration of dust particles, atmospheric turbulence, etc (Mohmand et al. 2015; Li et al. 2017). The presence of indoor dust is a serious issue with sit-at-home parents and sedentary individuals in the office while presence of heavy metals in such could increase the possible environmental issues that are associated with them (Darus et al. 2012). This may include increase in atmospheric solar radiation, concentration of total suspended solids and change in size of cloud condensation nuclei among others (Darus et al. 2012; Keshavarzi et al. 2015).

The infiltration of outdoor pollutants resulting from rock blasting, industrial discharge (Thorton 1991), vehicle emissions (Khoder et al. 2010), coal pulverization (Charlesworth et al. 2011), attached particles to footwear's are external sources of heavy metals in indoor dust due to outdoor $\leftrightarrow$ indoor equilibrium (Turner 2011). In contrast, paint composition such as pigment $\left(\mathrm{PbO}_{2}, \mathrm{TiO}_{2}\right.$, etc.) (Chattopadhyay et al. 2003), carpet backing (Fergusson and Kim 1991), indoor heating and combustion of fossil fuel (Turner, 2011), electrical appliances (Lau et al. 2014), etc. are internal sources of heavy metals in indoor dust. Exposure to indoor dust with a high concentration of heavy metals via ingestion, inhalation, and dermal contact can lead to inhibition of biochemical and neurological activities (Duruibe et al. 2007; Rout et al. 2015). The metals could undergo rapid chemical reactions owing to their reactivity and variable oxidation state. This may result in mutagenesis, genotoxicity, non-carcinogenic and carcinogenic health risk (Kang et al. 2011). This study is therefore designed to monitor the air quality of postsecondary institutions in Ondo state, Nigeria by evaluating the concentration of selected heavy 
metals in airborne particulate matter and thus estimating the potential human health risk associated with oral, respiratory and dermal contact from the selected heavy metals.

\section{Materials and methods}

\section{Sample collection}

Indoor dust samples used for this study were obtained during dry season (December - Mid March) from four higher institutions of learning in Ondo State, Nigeria. They include Federal University of Technology Akure (FUTA)-a university, Federal College of Agriculture (FECA)-a monotechnic, Ondo State College of Health Science Technology (OSCOHST)-a health college, Akure and Adeyemi College of Education (ACE). Selection of these higher institutions within the state was based on their proximity to more anthropogenic actions such as industrialization, urban construction, and automobile movement among other parameters. A total of $20 \mathrm{~g}$ air particulate matter samples were collected from each of the study sites by gently dusting surfaces of doors, windows, and bookshelves in different lecture rooms, hostels, laboratories and libraries with polyethylene brush, stored in polypropylene bottles until analysis. Samples obtained from FUTA were labeled as FU, those from FECA as FE, those from OSCOHST as HT and those from ACE as OA.

\section{pH determination}

The $\mathrm{pH}$ of the samples was determined by the method of Rowell et al. (1994). Briefly, $2 \mathrm{~g}$ of (each) sample was weighed into a beaker and $50 \mathrm{~mL}$ of distilled water was added. The mixture was left for $30 \mathrm{~min}$ and stirred at regular intervals. Upon completion, the electrode of a precalibrated Hanna pH meter (model HI2210 obtained from Italy) was dipped into the solution and the $\mathrm{pH}$ value was read and recorded.

\section{Conductivity determination}

The method of Rowell et al. (1994) was employed for conductivity determination. Typically, $2 \mathrm{~g}$ of (each) sample was weighed into a beaker and $50 \mathrm{~mL}$ of distilled water was added. The mixture was left for $30 \mathrm{~min}$ and stirred at regular intervals. Then, the conductivity was read with a conductivity meter (Jenway4520, UK), which was pre-calibrated using $1 \mathrm{M} \mathrm{KCl}$ at $25^{\circ} \mathrm{C}$. 
Analysis of anionic concentration of dust sample

$2 \mathrm{~g}$ of (each) sample was dissolved in $100 \mathrm{~mL}$ of distilled water in a $250 \mathrm{~mL}$ Erlenmeyer flask and placed in a mechanical shaker for $24 \mathrm{~h}$ for equilibration to prepare a stock sample. Thereafter, the solution was filtered and subsequently used for the determination of chloride, sulfate, and nitrate.

\section{Chloride content determination}

The chloride content of (each) sample was determined by Mohr's method (Meija et al. 2016). Typically, $2 \mathrm{~mL}$ of stock sample was taken and $0.02 \mathrm{~g}$ of $\mathrm{NaHCO}_{3}$ was added until effervescence ceased. Upon completion, $2 \mathrm{~mL}$ of $\mathrm{K}_{2} \mathrm{Cr}_{2} \mathrm{O}_{4}$ was introduced and stirred to enhance equilibration. The solution was titrated to the first permanent appearance of red $\mathrm{Ag}_{2} \mathrm{Cr}_{2} \mathrm{O}_{4}$. The percentage of chloride is calculated using the formula below.

Mole of $\mathrm{Cl}^{-}=V_{\mathrm{AgNO}} \times M_{\mathrm{AgNO}}$

Where, Mass of $\mathrm{Cl}^{-}=$Mole of $\mathrm{Cl}^{-} \times$Molar mass

$\% \mathrm{Cl}^{-}={ }^{\text {Mass of }^{-}} /$Sample mass $\times 100$

\section{Sulphate content determination}

The method of Samira et al. (2009) was adopted for the determination. Briefly, $5 \mathrm{~mL}$ (each) of stock sample was diluted up to $100 \mathrm{~mL}$ using distilled water and thereafter transferred into a 250 $\mathrm{mL}$ conical flask. $5 \mathrm{~mL}$ conditional reagents (a mixture of $50 \mathrm{~mL}$ glycerol, $30 \mathrm{~mL}$ conc. $\mathrm{HCl}$, $300 \mathrm{~mL}$ distilled water, $100 \mathrm{~mL} 95 \%$ ethanol and $75 \mathrm{~g}$ of $\mathrm{NaCl}$ ) were added and stirred. Afterward, $4 \mathrm{~mL}$ of $1 \mathrm{~N} \mathrm{HCl}$ and $5 \mathrm{~mL}$ of $4 \% \mathrm{BaCl}_{2}$ were added at room temperature. The resulting suspension was maintained at $400^{\circ} \mathrm{C}$ in the bath for $15 \mathrm{~min}$ before dilution and analyzed by using (Spectrum lab 752, England) UV Spectrophotometer (at $\lambda=420 \mathrm{~nm}$ ).

\section{Nitrate content determination}

The nitrate content of (each) sample was determined by the Phenoldisulphonic method adopting Samira et al. (2009). First, the concentration of chloride in each sample was determined. Typically, $3 \mathrm{~mL}$ of (each) sample was measured from the stock solution into the centrifuge tube and $100 \mu \mathrm{L}$ of silver sulfate was added. The volume was made up to $10 \mathrm{~mL}$ with distilled water. 
The tube was centrifuged for $10 \mathrm{~min}$ until the solution was clear. $5 \mathrm{~mL}$ of the clear solution was put in a glass evaporating dish, placed on a water bath at $50^{\circ} \mathrm{C}$ to evaporate to dryness, and cooled. Upon completion, $1 \mathrm{~mL}$ of phenoldisulphonic acid was added. After 10min, $10 \mathrm{~mL}$ of water was added, transferred to $100 \mathrm{~mL}$ volumetric flask, and was made alkaline by the addition of $2 \mathrm{~mL}$ conc. $\mathrm{NH}_{4} \mathrm{OH}$ followed by thorough mixing. The absorbance at $410 \mathrm{~nm}$ was measured by using a UV/ Visible Spectrophotometer; (Spectrum lab 752, England).

\section{Heavy metal determination}

$0.5 \mathrm{~g}$ of (each) sample was accurately weighed into a clean digesting flask and a $20 \mathrm{~mL}$ mixture of concentrated $\mathrm{HCl}$ and $\mathrm{HNO}_{3}(1: 3, \mathrm{v} / \mathrm{v})$ was added. The flask and content was heated gently in a fume cupboard for 5 minutes at $145^{\circ} \mathrm{C}$ and allowed to cool before filtering through a No. 42 Whatman filter paper into a 50mL volumetric flask (Perihan and Kurt 2012). The digestion flask was rinsed 3 times with $5 \mathrm{~mL}$ double distilled water and was added to the content of the volumetric flask before making to mark (Harrad et al. 2008). The digest was analysed for Co, Cd, $\mathrm{Cr}, \mathrm{Pb}$, and $\mathrm{Cu}$ using Flame Atomic Absorption Spectrophotometer (FAAS) model Buck Scientific SVG 210.

\section{Health risk assessment}

Considering the amount of time spent indoor by students daily within campus, the average daily dose of exposure to heavy metals are estimated by three core exposure pathways -(i) ingestion (ii) inhalation (respiratory), (oral) and (iii) dermal contact(skin) (Luo et al. 2012, USEPA 2014)

$A D D_{\text {Ingestion }}=\frac{C \times C F \times I R S \times F I \times E F \times E D}{B W \times A T}$

$$
A D D_{\text {Inhalation }}=\frac{C \times I R a \times E T \times E F \times E D}{P E F \times B W \times A T}
$$

$$
A D D_{\text {Dermal contact }}=\frac{C \times C F \times A F \times A B S \times E F \times E D \times E V \times S A}{B W \times A T}
$$

Where the exposure factors for dose model (in adults) areas follow: $I R s=30 \frac{\mathrm{mg}}{\text { day }} ;$ Exposure Frequency $=350\left(\frac{\text { day }}{\text { year }}\right) ;$ Exposure Duration $=$ 30 years; Average Time $(A T)=(E D \times 365)$ days; Body Weight $(B W)=$ 
$17170 \mathrm{~kg} ;$ Conversion Factor $=\frac{10^{-6} \mathrm{~kg}}{\mathrm{mg}} ;$ Fraction Ingested $(F I)=$

1721 ; Inhalation Rate $($ IRa $)=7.63 \frac{\mathrm{m}^{3}}{\text { hour }} ;$ Dermal Absorption Factor $(A B S)=$

$1730.001 ;$ Adherence Factor $(A F)=0.07 ;$ Exposure Time $(E T)=$

$17414 \frac{\text { hours }}{\text { day }} ;$ Surface Area $(S A)=5700 \mathrm{~cm}^{2} ;$ Particulate Emission Factor $(P E F)=1.36 \times$

$175 \frac{10^{9} \mathrm{~kg}}{\mathrm{~m}^{3}} ;$ Event Frequency $(E V)=1$ event/day (USEPA 2001; USEPA 2004; IRIS 2018)

176 Non-carcinogenic risk assessment

177 The non-carcinogenic effect canbe investigated by estimating the hazard quotient (HQ) and 178 hazard index (HI) of each metal.

$179 \mathrm{HQ}=\mathrm{ADD} / \mathrm{RfD}$

180

$$
\mathrm{HI}=\sum_{\mathrm{n}=1}^{\mathrm{n}} \mathrm{HQ}=\sum_{\mathrm{n}=1}^{\mathrm{n}} \mathrm{A}_{\mathrm{i}} / \mathrm{D}_{\mathrm{i}}=\mathrm{A}_{1} / \mathrm{D}_{1}+\mathrm{A}_{2} / \mathrm{D}_{2}+\mathrm{A}_{3} / \mathrm{D}_{3}+\cdots \mathrm{A}_{\mathrm{n}} / \mathrm{D}_{\mathrm{n}}
$$

181

182

183

184

185

186

187

188

189

190

191

192

193

194

195

Where,

$$
A_{1}, A_{2}, A_{3}, \ldots A_{n} \text { is the average daily dose (ADD) of each metal in the mixture of } n
$$

metal present in the samples through the different pathways (ingestion, inhalation or dermal contact) and $D_{1}, D_{2}, D_{3}, \ldots D_{n}$ are the reference dose of each metal (USEPA 2001).

Generally, HQ and $\mathrm{HI} \leq 1$ implies no adverse effect while $>1$ indicates potential adverse effect (USEPA 2001; Li et al. 2018)

\section{Statistical analysis}

The data obtained in this study were subjected to statistical analysis using MS Excel. The arithmetic mean, range and standard deviation (SD) for the analysis of heavy metal concentration in the samples were determined (Yangbing et al. 2019). Correlation of variance $(\mathrm{CV})=S D /$ Mean $\times 100$ was calculated to show the distribution pattern of the heavy metals and other parameters in the samples. ANOVA was also used to determine the distribution differences based on mean concentrations.

Results and discussion

\section{Results of physicochemical analysis}


The results of physicochemical properties ( $\mathrm{pH}$, conductivity; levels of anions) of the dust samples obtained from the four different universities -FUTA (represented as FU), FECA (represented as FE), OSCOHST (represented as HT) and ACE (represented as OA) are presented in Table 1. The alkalinity and acidity of indoor dust have been found to depend on the sources and seasonal variation (Wu et al. 2013). Although, sampling in this study was done during the dry season which have dustier event thereby increasing the background $\mathrm{pH}$ of the indoor dust. From the study, the $\mathrm{pH}$ ranges from 6.39-7.13 with the minimum value in the sample obtained from HT and maximum from FU; they are within neutral $\mathrm{pH}$. This accounted for the low concentration of acidic oxides found in the samples. Furthermore, there is similarity in the results obtained with that obtained by $\mathrm{Wu}$ et al. (2013) for similar study in Lanzhou China at different seasons: spring (6.87) and summer (6.81). Consequently, the findings showed that the conductivity of the sample increases from 232 to 348. This show a wide variability compared to the $\mathrm{pH}$ values. However the trend observed in the study sites was $\mathrm{OA}>\mathrm{HT}>\mathrm{FE}>\mathrm{FU}$.

$\mathrm{NO}_{3}{ }^{-}$content of $0.01 \mathrm{mg} / \mathrm{L}$ was estimated in $\mathrm{FU}$, a sample from the Federal University of Technology, Akure while $0.02 \mathrm{mg} / \mathrm{L}$ was obtained in other samples (FE, HT and OA). Latif et al. (2008) reported a mean of $0.02 \mathrm{mg} / \mathrm{L}$ for nitrate composition of household dust in Malaysia, which is in agreement with the findings of the present study. Notably, inorganic ions are usually employed for pollutant source identification and apportionment studies in indoor dust (Hassan 2012).Indoor-outdoor exchange could be responsible for the reported nitrate values. However, indoor sources such as burning candles and incense, cooking, and smoking activities are to be considered as well (Schladitz et al. 2015).

The mean level of sulfate obtained was $0.07 \mathrm{mg} / \mathrm{L}$, with least concentration $(0.04 \mathrm{mg} / \mathrm{L})$ in FU sample and highest $(0.1 \mathrm{mg} / \mathrm{L})$ sample from OA, following a decreasing trend $\mathrm{OA}>\mathrm{HT}>\mathrm{FE}>\mathrm{FU}$. These values are lower than that reported by Latif et al. (2008) in Malaysia with the mean value of $27.42 \mathrm{mg} / \mathrm{L}$ for sulfate composition of household dust. Cooking activities, cleaning agents and chlorinated tap water are sources of sulfate in indoor dust.

The percentage chloride concentration obtained ranged from 0.15 to 0.46 , with a mean of 0.27 . FU sample contains the highest mean concentration of chloride followed by FECA samples, College of Health Technology samples and College of Education samples in the order. The 
major sources of chloride in household dust are detergents containing chlorides while sulphate and nitrate are mostly due to combustion activities within the indoor environment (Men et al. 2018). Anionic and cationic surfactants found in indoor dust are mainly from synthetic surfactants found in consumer products (Lau et al. 2014). Summarily, the mean levels of nitrates in all samples $(0.01-0.02 \mathrm{mg} / \mathrm{L})$ are less than the mean of sulfate $(0.04-0.10 \mathrm{mg} / \mathrm{L})$ and \%chloride $(0.15-0.460)$. The level of the anion in this study corresponds with the level of such activities in the sample sites. However, all the values are lower than those reported by Latif et al. (2008) for anions in the stairway and other indoor dust samples. The sequence of concentration level was however as follows, $\mathrm{Cl}^{-}>\mathrm{SO}_{4}{ }^{2-}>\mathrm{NO}_{3}{ }^{-}$.

\section{TABLE 1}

\section{Heavy metal concentration in indoor dust}

The selected heavy metal concentrations determined in the samples are shown in Table 2. Previous studies on indoor air quality showed that the composition of pollutants (heavy metals) in household dust depends on the indoor-outdoor interactions (Azmat et al. 2014; Gao et al. 2017).

For Lead $(\mathrm{Pb})$, the mean concentration was obtained in the range of $0.02-0.11 \mathrm{mg} / \mathrm{kg}$ with the highest in-dust sample from FECA and least in FUTA. The overall mean concentration of $\mathrm{Pb}$ was calculated to be $0.0625 \mathrm{mg} / \mathrm{kg}$ and is in the range of values reported by Olatunde et al. (2016) on the levels of the metal in indoor dust around tertiary institutions. The concentration of $\mathrm{Pb}$ was also found to be slightly lower than reported data from neighboring African city, Ketu, Ghana (Addo et al. 2012), and even from similar sites in Lagos State, Nigeria (Popoola et al. 2012). The relatively low concentration for $\mathrm{Pb}$ could be ascribed to a low level of industrial activities around the study area and as well ban on the use of lead $(\mathrm{Pb})$ as additive in fuel and pigments in paints. Hence, low tendencies from anthropogenic actions. Additionally, the $\mathrm{Pb}$ concentrations were fairly uniform and fell below $0.1 \mathrm{mg} / \mathrm{kg}$ except for sample collected from FE $(0.11 \mathrm{mg} / \mathrm{kg})$.This could be as a result of the very old building of the collection site, causing the paints to peel and settle on the floor as specks of dust. This showed that gloss and emulsion paint use in Nigeria consists of substantial levels of $\mathrm{Pb}$ (Rashed 2008). 
The concentrations of cadmium (Cd) were below the detection limit (ND) for the FU sample while the Cd concentration detected in the other samples was between $0.01-0.02 \mathrm{mg} / \mathrm{kg}$, which were lower than the average concentration in the earth's crust (Adekola and Dosunmu 2001). The value obtained in this study is relatively low compared with $0.175-0.722 \mathrm{mg} / \mathrm{kg}$ and $0.12-$ 0.380mg/kg reported by Rashed (2008) and Adekola and Dosunmu (2001) respectively. Even though cadmium is carcinogenic and can damage the blood vessel system, the Cd concentrations obtained in this study were below permissible level and hence there is however little/no need to worry.

The mean concentration of chromium $(\mathrm{Cr})$ in the dust samples is $0.185 \mathrm{mg} / \mathrm{kg}$ and a range of $0.12-0.25 \mathrm{mg} / \mathrm{kg}$. Samples collected from FECA (FE) had the highest Cr concentration with those from College of Health Technology (HT) as the least. The mean value of chromium is thus higher than that obtained for cadmium and lead. Dust from the sample sites is, therefore, more exposed to chromium sources than lead or cadmium sources. These values are however lower than $17.37 \mathrm{mg} / \mathrm{kg}$ (Popoola et al. 2012). Chromium is used in alloys, electroplating, pigments, and paint manufacture (Kang et al. 2011). Automobiles and electronic waste are sources of metallic chromium in the environment (Musa et al. 2009).

$\mathrm{Zn}$ is one of the most spread elements in the earth's crust (air, soil, and water) (Musa et al. 2009). It fastens to dust particles and settles as $\mathrm{Zn}$ dust particles. The mean concentration of $\mathrm{Zn}$ was in the range of $0.11-0.25 \mathrm{mg} / \mathrm{kg}$ with a mean of $0.21 \mathrm{mg} / \mathrm{kg}$, which is higher than the levels of chromium, lead, and cadmium discussed above. This indicates that the environments were exposed to more zinc sources. Additionally, the level of $\mathrm{Zn}$ was highest in OA, a sample collected from Adeyemi College of Education, and least in HT, a sample from the College of Health Technology. The natural range of zinc in soils is $10-300 \mathrm{mg} / \mathrm{kg}$ (Musa et al. 2009), while in indoor dust; it is expected to be lower than that. The concentrations of zinc were within these natural ranges and are significantly smaller than those reported in other studies. For example, a range of $4-42 \mathrm{mg} / \mathrm{kg}$ was reported by Eneji et al. (2015).

The average concentration of copper obtained was $0.23 \mathrm{mg} / \mathrm{kg}$, which is higher than the mean of each of the other metals. However, the values fall within the range $0.18-0.31 \mathrm{mg} / \mathrm{kg}$ with highest in FE, a sample from FECA and lowest in OA, a sample from the Adeyemi College of 
Education. The values were lower than the range $0.190-1.990 \mathrm{mg} / \mathrm{kg}$ (Adekola and Dosumu 2001), $5.65-11.30 \mathrm{mg} / \mathrm{kg}$ (Samson 2019) and $2.20-14.00 \mathrm{mg} / \mathrm{kg}$ (Wahab et al. 2012). The high level of copper-plated utensils and copper wires used in homes is the major sources of copper in environmental medium and indoor dust (Kim et al. 2015). However, learning difficulties, antisocial and hyperactive behavior among others are the adverse health effects of high copper exposure (Kim et al. 2015). Generally, all the metals investigated $(\mathrm{Cu}, \mathrm{Pb}, \mathrm{Cd}, \mathrm{Cr}$, and $\mathrm{Zn}$ ), were found to be relatively below the permissible level of heavy metals in indoor dust (Olatunde et al. 2016).

\section{TABLE 2}

\section{Estimation of the calculated average daily dose}

\section{Estimation of the calculated average daily dose}

The estimation of calculated average daily dose (ADD) of heavy metals in each dust sample is presented in Figure 1. The average daily doses (ADD) of heavy metals were determined based on exposure via ingestion, dermal contact and inhalation denoted as $\mathrm{ADD}_{\text {ing, }}, \mathrm{ADD}_{\text {derm }}$ and $\mathrm{ADD}_{\text {inh }}$ respectively. Selection of these higher institutions within the state was based on their proximity to more anthropogenic actions such as industrialization, urban construction, and automobile movement among other parameters. From Figure 1, the trends observed for the average daily exposure dose in the study were in the order $A D D_{\text {ing }}>A D D_{\text {derm }}>A D D_{\text {inh }}$, which implies that ingestion is the major pathway of exposure with inhalation the least. This is similar to other studies (Izhar et al. 2016; Gope et al. 2017). However, the ADD of the heavy metals followed the decreasing order $\mathrm{Cu}>\mathrm{Zn}>\mathrm{Cr}>\mathrm{Pb}>\mathrm{Cd}$ for various pathway. Values reported are lower than the ADD reported for a similar study in Lagos state primary school, Nigeria by Olatunde et al. (2016).

\section{FIGURE 1}

\section{Non-carcinogenic risk of heavy metals in indoor dust}


The non-carcinogenic risk of the studied metalss was assessed via the three exposure pathways considered in the present work using the hazard quotients (HQ) and hazard indices (HI) of metal intake from the samples. HQ and HI were determined as presented in Table 3. The calculated HQ ranged from $3.93 \times 10^{-10}$ to $5.920 \times 10^{-5}$. The trend in the HQ obtained from the study sites was in the order $\mathrm{FE}>\mathrm{OA}>\mathrm{HT}>\mathrm{FE}$. However, the magnitudes of the HQ were below $1 \times 10^{-4}$. Consequently, remediation of the study sites is not needed (Zheng et al. 2010a).It was observed that for most of the study sites that the $\mathrm{HI}$ reported for the metals was $\mathrm{Cr}>\mathrm{Pb}>\mathrm{Cd}>\mathrm{Cu}>\mathrm{Zn}$. The results were at variance with previous report $\mathrm{Pb}>\mathrm{Cd}>\mathrm{Zn}>\mathrm{Cu}>\mathrm{Cr}$ for street dust (Hu et al. 2011). Generally, the HQ and HI reported are less than 1 respectively, which implies there is no potential non-carcinogenic effect in the sites, indicating no health risk for the students and their tutors (IRIS 2018)

\section{Conclusion}

This study reveals that the variations in the heavy metal composition in indoor dust of the study site are below the permissible level. Also, study showed that no health risk associated is associated with 3 exposure pathways. Consequently, the HQ and HI reported was relatively less than 1, which implies no potential non-carcinogenic human health risk. Hence, there is no constant concentration of a particular pollutant in environment; frequent monitoring of the quality of the indoor dust in this academic environment should be recommended. More so, efforts and regulations should be in place to maintain this status quo of non-contamination of these areas of studies.

\section{Declaration}

\section{Ethical Approval}

The study do not involved experimentation on animals or man.

\section{Consent to participate}

$$
\text { N/A }
$$

\section{Consent to Publish}

All authors gave their approval for the manuscript publication. 


\section{Author's contribution}

OOA conceptualized the idea and was involved in performing the experiments, writing, reviewing and editing the original draft. ATA, AO and TOO were involved in formal analysis and writing of the original draft preparation; AMA and OBO reviewed and edited the work. JIO involved in supervision, wrote, reviewed and edited the original draft.

\section{Funding}

No funding was received for this work.

\section{Competing Interest}

All authors have no conflict of interest to disclose.

\section{Availability of data and materials}

This data herein are original research work and has not been submitted for publication elsewhere.

\section{Reference}

Addo IG, Mohai P, Kweon BS, Lee SK (2012). Air pollution around schools is linked to poorer student health and academic performance, Journal of Epidemiology Community Health 65(6), 852-862.

Adekola FA and Dosumu OO (2001). Heavy Metal Determination in Household Dust from Ilorin City, Nigeria. Journal Nigeria Society for Experimental Biology, 3(1) 217-221.

Azmat Z, Muhammad ZH, Riffat NM, Zulkifl, A (2014) Enrichment and geo-accumulation of heavy metals and risk assessment of sediments of the KurangNallah-Feeding tributary of the Rawal Lake Reservoir, Pakistan. Sci. Total Environ. 470-471, 925-933.

Charlesworth S, De Miguel E, Ordonez A (2011) A review of the distribution of particulate trace elements in urban terrestrial environments and its application to considerations of risk.Environ Geochem Health, 33, 103-123

Chattopadhyay G, Lin C-PK, Feitz AJ (2003) Household dust metal levels in the Sydneymetropolitan area. Environ Res; 93, 301-7. 
Darus FM, Nasir RA, Sumari SM, Ismail ZS, Omar NA (2012) Heavy metals composition of indoor dust in nursery schools building. Procedia Soc. BehavSci, 38, 169-75.

Duruibe JO, Ogwuebu MOC, Egwurugwuu JN (2007) Heavy Metal Pollution and Human Biotoxic Effects. Int. Physical Sci., 2(5), 112-118

Eneji IS, Itodo U, Adams, K, Julius A (2015) Assessment of Heavy Metals in Indoor Settled Harmattan Dust from the University of Agriculture Makurdi, Nigeria. Open Journal of Air Pollution, 4, 198-207.

Fergusson JE, Kim, ND (1991) Trace elements in street and house dusts: sources and speciation. Sci. Total Environ. 100, 125-150

Gao P, Lei T, Jia L, Song Y, Lin N, Du Y, Feng Y, Zhang Z, Cui F (2017) Exposure and health risk assessment of PM2.5-bound trace metals during winter in university campus in Northeast China. Sci. Total Environ., 576, 628-636.

Gope M, Masto RE, George J, Hoque RR, Balachandran S (2017). Bioavailability and health risk of some potentially toxic elements $(\mathrm{Cd}, \mathrm{Cu}, \mathrm{Pb}$ and $\mathrm{Zn})$ in street dust of Asansol, India. Ecotoxicol. Environ. Safe 138, 231-241.

Harrad S, Ibarra C, Diamond M, Melymuk L, Robson M, Douwes J, et al. (2008). Polybrominated diphenyl ethers in domestic indoor dust from Canada, New Zealand, United Kingdom and United States. Environ Int; 34:232-8.

Hassan SKM (2012) Metal concentrations and distribution in the household, stairs and entryway dust of some Egyptian homes. Atmos Environ; 54, 207-15.

Hu X, Zhang Y, Luo J, Wang T, Lian H, Ding Z (2011) Bioaccessibility and health risk of arsenic, mercury and other heavy metals in urban street dusts from a mega-city, Nanjing, China. Environ Pollut; 159.

Ibigbami OA, Adefemi SO, Asaolu SS, Orege JI, Adesina AJ, Popoola OK, Azeez MA, Akinsola AF, Olatoye RA (2020). Assessment of toxic metals in some selected cosmetics products in Nigeria and their health risk. Rev. Chim, 71(9): 39-46

IRIS (Integrated Risk Assessment System) (2018) United States Environmental Protection Agency. 1995. Available online: www.epa.gov/IRIS/ (accessed on 15 April 2018). 
Izhar S, Goel A, Chakraborty A, Gupta T (2016). Annual trends in occurrence of submicron particles in ambient air and health risk posed by particle bound metals. Chemosphere, 146, $582-590$.

Juris M, Michałowska-Kaczmarczyk AM, Tadeusz M, (2016) Mohr's method challenge Anal BioanalChem 408, 1721-1722 DOI 10.1007/s00216-015-9273-2

Kang Y, Cheung KC, Wong MHN (2011) Mutagenicity, genotoxicity and carcinogenic risk assessment of indoor dust from three major cities around the Pearl River Delta. Environ Int, $37,637-43$

Keshavarzi B, Tazarvi Z, Rajabzadeh M, Najmeddin A (2015) Chemical speciation, human health risk assessment and pollution level of selected heavy metals in urban street dust of Shiraz, Iran. Atmos. Environ, 119, 1-10.

Khoder MI, Hassan SK, El-Abassawy AA (2010) An evaluation of loading rate of dust, $\mathrm{Pb}, \mathrm{Cd}$ and $\mathrm{Ni}$ and metals mass concentration in the settled surface dust in domestic houses and factors affecting them. Indoor and Built Environment 19(3), 391-399.

Kim HS, Kim YJ, Seo YR (2015). An Overview of Carcinogenic Heavy Metal: Molecular Toxicity Mechanism and Prevention. Asian Pac. J. Cancer Prev., 20, 232-240.

Kurt-Karakus PB, (2012) Determination of heavy metals in indoor dust from Istanbul, Turkey: Estimation of the health risk; Environment International 50;47-55

Latif MT, Mohamed RO, Chong LK, Siti AM, KhairulNazri AS (2008) Composition of Household Dust in Semi-urban Areas in Malaysia. Indoor Built Environment, 18(2), 155161.

Lau WKY, Liang P, Man YB, Chung SS, Wong MH (2014) Human health risk assessment based on trace metals in suspended air particulates, surface dust, and floor dust from e-waste recycling workshops in Hong Kong, China. Environ SciPollut Res, 21, 3813-3825

Li H, Wu H, Wang Q, Yang M, Li F, Sun Y, Qian X, Wang J, Wang C (2017) Chemical partitioning of fineparticle bound metals on haze-fog and non-haze-fog days in Nanjing, China and its contribution to humanhealth risks. Atmos. Res.183, 142-150.

Li N, Han W, Tang J, Bian J, Sun S, Song T (2018) Pollution characteristics and human health risks of elements in road dust in Changchun, China. Intl. J. Environ. Res. Public Health, 15, 1843, doi:10.3990/ijerph15091843. 
Li $\quad$ Y, Fang F, Lin Y, Wang Yue, Kuang Y, Wu M, (2019). Heavy metal contamination and health risks of indoor dust around XinqiaoMining Area, Tongling, China, Human and Ecological Risk Assessment: An International Journal, DOI: 10.1080/10807039.2018.1503930.

Luo XS, Ding J, Xu B, Wang YJ, Li HB, et al.(2012) Incorporating bio accessibility into human health risk assessments of heavy metals in urban park soils. Sci Total Environ; 424, 88-96.

Men C, Liu R, Xu F, et al.(2018) Pollution characteristics, risk assessment, and source apportionment of heavy metals in road dust in Beijing, China. Sci Total Environ.; 612:138147. doi:10.1016/j.scitotenv.2017.08.123.

Mohmand J, Eqani SAMAS, Fasola M, Alamdar A, Mustafa I, Ali N, Liu L, Peng S, Shen H, (2015) Human exposure to toxic metals via contaminated dust: Bio-accumulation trends and their potential risk estimation. Chemosphere 132, 142-151.

Musa L, Sandra T, Makinwa SK, (2009). House Dust and the Heavy Death.Atmospheric Environment, 36, (4767 - 4779.

Olatunde SD, Joshua NE, Popoola OE, Odiyo JO, (2016) Health Risk Assessment of Heavy Metals on Primary School Learners from Dust and Soil within School Premises in Lagos State, Nigeria http://dx.doi.org/10.5772/intechopen.74741

Popoola OE, Bamgbose O, Okonkwo OJ, Arowolo TA, Popoola AO, Awofolu OR, (2012). Heavy metals content in classroom dust of some public primary schools in metropolitan Lagos, Nigeria. Research Journal of Environmental and Earth Sciences, 4 (4), 460-465.

Rashed MN, (2008) Total and Extractable Heavy Metals in Indoor, Outdoor and Street Dust from Nigerian Cities. Clean Environment Journal, 36(10 - 11), 850 - 857.

Rout TK, Masto RE, Ram LC, George J, Padhy PK, (2015) Assessment of human health risks from heavy metals in outdoor dust samples in a coal mining area. Environ Geochem Health 35:347 - 56 .

Rowell D, (1994) Soil Science Methods and Applications. Longman Press, UK,.

Saeedi M, Li LY, Salmanzadeh M, (2012) Heavy metals and polycyclic aromatic hydrocarbons: Pollution andecological risk assessment in street dust of Tehran. J. Hazard. Mater. 227-228, 9-17. 
Samira AB, Hawaa SE, Haroun FA, Fatma FA, (2009) Determination of available Nitrate, Phosphate and Sulfate in soil sample. International journal of Pharm Tech Research, 1(3) pp 598-604.

Sanni SO, (2019). Determination of heavy metals ( $\mathrm{Pb}, \mathrm{Cu}$ and $\mathrm{Cd}$ ) in dust from selected households in Kano city, Nigeria. International Journal of Advanced Academic Research | Sciences, Technology \& Engineering | ISSN:5(1) (2019) 2488-9849.

Schladitz A, Lenícek J, Beneš I, Kovác M, Skorkovský J, Soukup A, Jandlová J, Poulain L, Plachá H, Löschau G, et al.(2015) Air quality in the German-Czech border region: A focus on harmful fractions of PM and ultrafine particles. Atmos. Environ., 122, 236-249.

Thorton, L, (1991) Metal contamination of soils in urban areas. In: Soils in the Urban Environment. (P. Bullock and P.J. Gregory, eds.), Black Scientific Publications, Oxford, U.K, pp.47-75.

Titilayo Y, Adeniji A, Adeniji M, Okoh A, (2018). Chemosphere; 211, 834-843.

Turner, A.,(2011) Oral bioaccessibility of trace metals in household dust: a review. Environ Geochem Health33,331-341

US EPA (U.S. Environmental Protection Agency).(2001) Risk Assessment Guidance for Superfund: Volume III-Part A, Process for Conducting Probabilistic Risk Assessment; Office of Emergency and Remedial Response, US EPA: Washington, DC, USA, December 2001.

U.S. EPA (U.S. Environmental Protection Agency) (2004) Risk Assessment Guidance for Superfund Volume I: Human Health Evaluation Manual (Part E, Supplemental Guidance for Dermal Risk Assessment); Office of Superfund Remediation and Technology Innovation: Washington, DC, USA.

US EPA (U.S. Environmental Protection Agency) (2014) Framework for Human Health Risk Assessment to Inform Decision Making; EPA/100/R-14/001; Risk Assessment Forum, US EPA: Washington, DC, USA.

Wahab NAA, Darus FM, Isa N, Sumari SM, Hanafi NFM, (2012). Heavy metal concentration of settled surface dust in residential building. The Malaysian Journal of Analytical Sciences, 16(1) $18-23$. 
Wang W, Simonich SLM, Xue M, Zhao J, et al.. (2010) Concentrations, sourcesand spatial distribution of polycyclic aromatic hydrocarbons in soils from Beijing, Tianjin and surroundingareas, North China. Environ. Pollut. 18, 1245-1251

Wu D, Wang S, Xia J, Meng X, Shang K, Xie Y, Wang R (2013) The influence of dust events on precipitation acidity in China Atmospheric Environment, 79, 138-146

Wu H, Zhang YF, Han SQ, Wu JH, Bi XH, Shi GL, Wang J, Yao Q, Cai ZY, Liu JL, et al.(2015) Vertical characteristics of PM2.5 during the heating season in Tianjin, China. Sci. Total Environ. 523, 152-160.

Zhang X, Wang L, Wang W, Cao D, Wang X, Ye D, (2015) Long-term trend and spatiotemporal variations of haze over China by satellite observations from 1979 to 2013. Atmos. Environ. 119, 362-373.

Zheng N, Liu J, Wang Q, Liang Z (2010a). Health risk assessment of heavy metal exposure to street dust in the zinc smelting district, northeast of China. Sci Total Environ; 408:726-33.

Zheng Y, Che H, Zhao T, Zhao H, Gui K, Sun T, An L, Yu J, Liu C, Jiang Y, et al.(2017) Aerosol optical properties observation and its relationship to meteorological conditions and emission during the Chinese National Day and Spring Festival holiday in Beijing. Atmos. Res. 197, 188-200. 
Table1: Physicochemical properties of the indoor dust samples

\begin{tabular}{|c|c|c|c|c|c|}
\hline \multirow[t]{2}{*}{ Parameters } & \multicolumn{4}{|l|}{ Samples } & \multirow[t]{2}{*}{ Range } \\
\hline & FU & $\overline{\mathbf{O A}}$ & HT & $\overline{F E}$ & \\
\hline $\mathrm{pH}$ & $7.05 \pm 0.17(2.41)$ & $7.09 \pm 0.12(1.69)$ & $6.39 \pm 00(0)$ & $7.13 \pm 0.04(0.56)$ & $6.39-7.13$ \\
\hline Conductivity & $232 \pm 9.49(4.09)$ & $348.20 \pm 6.22(1.79)$ & $314.20 \pm 6.61(2.10)$ & $270.80 \pm 8.96(3.3)$ & $232-348.20$ \\
\hline $\mathrm{NO}_{3}^{-}(\mathrm{mg} / \mathrm{L})$ & $0.01 \pm 0.00(0)$ & $0.02 \pm 00(0)$ & $0.02 \pm 00(0)$ & $0.02 \pm 0.0(0)$ & $0.01-0.02$ \\
\hline $\mathrm{SO}_{4}{ }^{2-}(\mathrm{mg} / \mathrm{L})$ & $0.04 \pm 0.01(25)$ & $0.10 \pm 0.01(100)$ & $0.06 \pm 0.01(16.67)$ & $0.08 \pm 0.01(12.50)$ & $0.04-0.10$ \\
\hline$\% \mathrm{Cl}^{-}$ & $0.460 \pm 0.07(15.22)$ & $0.15 \pm 0.04(26.67)$ & $0.18 \pm 0.03(16.67)$ & $0.28 \pm 0.06(21.43)$ & $0.15-0.460$ \\
\hline
\end{tabular}

Results were expressed as Mean $\pm \operatorname{SD}(\mathrm{CV})$ for three independent samples $(n=3)$

Location of sample: FU: Federal University of Technology, Akure; FE: Federal College of Agriculture; HT: Ondo State College of Health Science Technology;OA:Adeyemi College of Education

Table 2: Mean concentrations of heavy metals in indoor dust $(\mathrm{mg} / \mathrm{kg})$

\begin{tabular}{llllll}
\hline Parameters & Samples & & & \multirow{2}{*}{ Range } \\
\cline { 2 - 5 } & FU & OA & HT & FE & \\
\hline Pb & $0.02 \pm 0.01(50)$ & $0.07 \pm 0.03(42.89)$ & $0.05 \pm 0.03(60)$ & $0.11 \pm 0.03(27.27)$ & $0.02-0.11$ \\
$\mathbf{C d}$ & ND & $0.01 \pm 0.00(0)$ & $0.01 \pm 0.00(0)$ & $0.02 \pm 0.01(50.00)$ & ND-0.02 \\
$\mathbf{C r}$ & $0.170 . \pm 0.05(29.41)$ & $0.20 \pm 0.12(60)$ & $0.12 \pm 0.07(58.33)$ & $0.25 \pm 0.18(72.00)$ & $0.12-0.25$ \\
$\mathbf{Z n}$ & $0.230 \pm 0.09(39.13)$ & $0.25 \pm 0.13(52)$ & $0.11 \pm 0.04(36.36)$ & $0.24 \pm 0.10(41.67)$ & $0.11-0.25$ \\
$\mathbf{C u}$ & $0.200 \pm 0.16(80)$ & $0.18 \pm 0.08(1.44)$ & $0.24 \pm 0.15(62.50)$ & $0.31 \pm 0.11(35.48)$ & $0.18-0.31$ \\
Total metals & 0.620 & 0.710 & 0.53 & 0.93 & $0.620-0.93$ \\
\hline
\end{tabular}

Note: ND denoted not detected

Results were expressed as Mean $\pm \operatorname{SD}(C V)$ for three independent samples $(n=3)$

Location of sample: FU: Federal University of Technology, Akure; FE: Federal College of Agriculture; HT: Ondo State College of Health Science Technology;OA:Adeyemi College of Education 


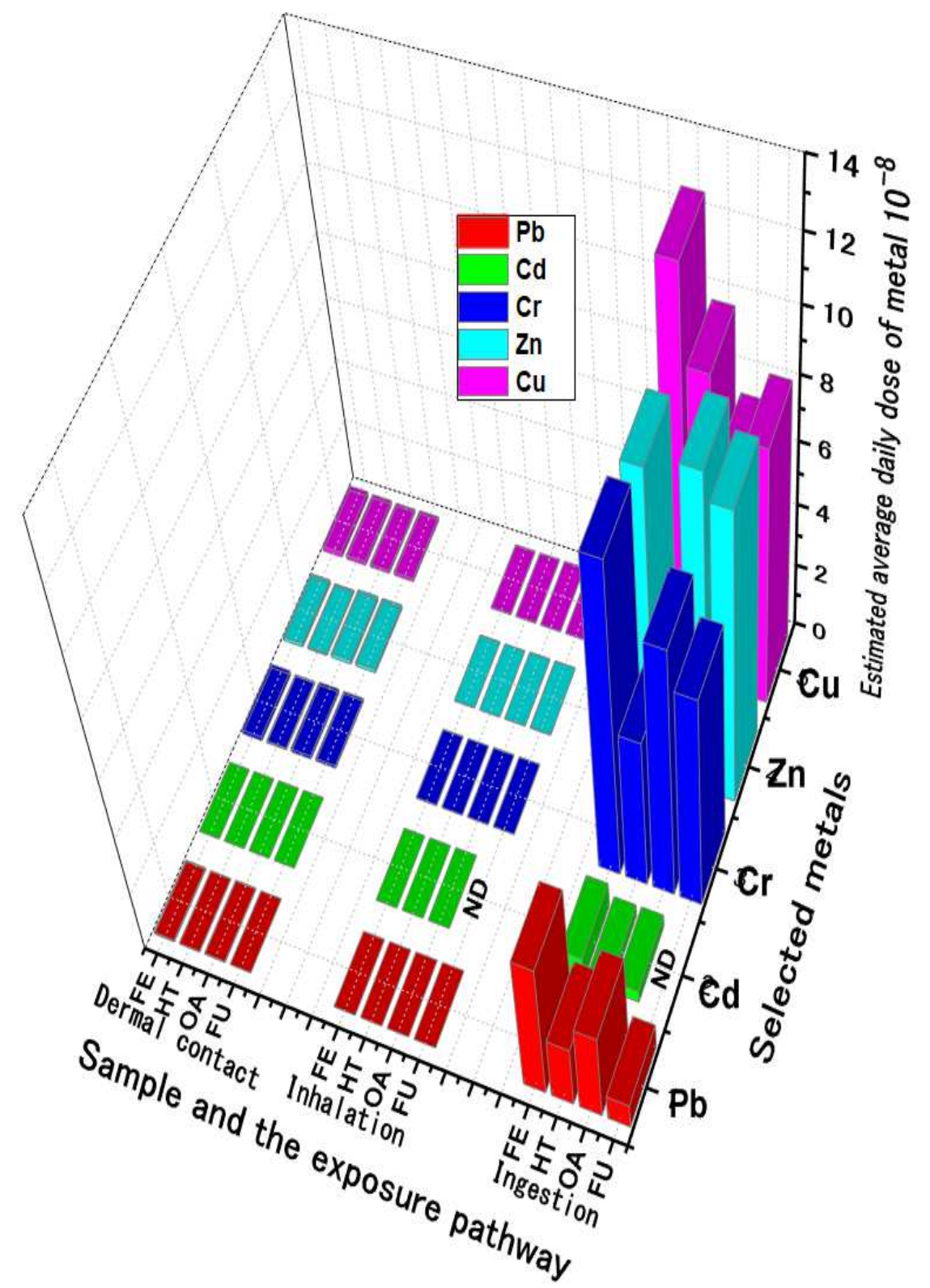

Note: ND denoted not detected

Location of sample: FU: Federal University of Technology, Akure; FE: Federal College of Agriculture;

HT: Ondo State College of Health Science Technology; OA:Adeyemi College of Education

Figure 1: Estimated average daily dose of heavy metals in the dust samples 
504 Table 3: Hazard quotient (HQ) and Hazard index of heavy metal in the dust samples

\begin{tabular}{llllllll}
\hline Exposure pathway & Sample & $\mathbf{P b}\left(\mathbf{1 0}^{-\mathbf{8}}\right)$ & $\mathbf{C d}\left(\mathbf{1 0}^{-\mathbf{8}}\right)$ & $\mathbf{C r}\left(\mathbf{1 0}^{-\mathbf{8}}\right)$ & $\mathbf{Z n}\left(\mathbf{1 0}^{-\mathbf{8}}\right)$ & $\mathbf{C u}\left(\mathbf{1 0}^{-\mathbf{8}}\right)$ & $\mathbf{H I}\left(\mathbf{1 0}^{-\mathbf{8}}\right)$ \\
\hline Ingestion & & & & & & & \\
& FU & 235 & ND & 2330 & 31.5 & 222 & 2820 \\
& OA & 823 & 411 & 2740 & 34.3 & 199 & 4210 \\
& HT & 586 & 411 & 1640 & 15.1 & 266 & 2920 \\
Inhalation & FE & 1290 & 822 & 3430 & 32.9 & 342 & 5920 \\
& & & & & & & \\
& FU & 0.615 & ND & 6.10 & 0.0823 & 0.580 & 7.38 \\
& OA & 2.15 & 1.08 & 7.17 & 0.0897 & 0.523 & 11.0 \\
& HT & 1.54 & 1.08 & 4.30 & 0.0393 & 0.695 & 7.65 \\
Dermal contact & FE & 3.38 & 2.15 & 8.97 & 0.0860 & 0.9 & 15.5 \\
& & & & & & & \\
& FU & 3.12 & ND & 30.9 & 0.420 & 2.94 & 37.4 \\
& OA & 10.9 & 5.46 & 36.3 & 0.457 & 2.65 & 55.8 \\
& HT & 7.80 & 5.46 & 21.8 & 0.2 & 3.53 & 38.8 \\
& FE & 17.2 & 10.9 & 45.7 & 0.437 & 4.56 & 78.8 \\
\hline
\end{tabular}

Reference dose (RfD) of heavy metals via ingestion: $\mathrm{Pb}=3.5 \mathrm{E}-3 ; \mathrm{Cd}=1.0 \mathrm{E}-3 ; \mathrm{Cr}=3.0 \mathrm{E}-3 ; \mathrm{Zn}=3.70 \mathrm{E}-2 ; \mathrm{Cu}=0.30$

Reference dose (RfD) of heavy metals via inhalation: $\mathrm{Pb}=3.52 \mathrm{E}-3 ; \mathrm{Cd}=1.0 \mathrm{E}-3 ; \mathrm{Cr}=2.86 \mathrm{E}-5 ; \mathrm{Zn}=4.02 \mathrm{E}-2 ; 0.30$

Reference dose (RfD) of heavy metals via dermal contact: $\mathrm{Pb}=5.25 \mathrm{E}-4 ; \mathrm{Cd}=5.0 \mathrm{E}-3 ; \mathrm{Cr}=2.5 \mathrm{E}-4 ; \mathrm{Zn}=1.90 \mathrm{E}-3 ; 6.0 \mathrm{E}-2$

Note: ND denoted not detected

Location of sample: FU: Federal University of Technology, Akure; FE: Federal College of Agriculture; HT: Ondo

State College of Health Science Technology; OA: Adeyemi College of Education 


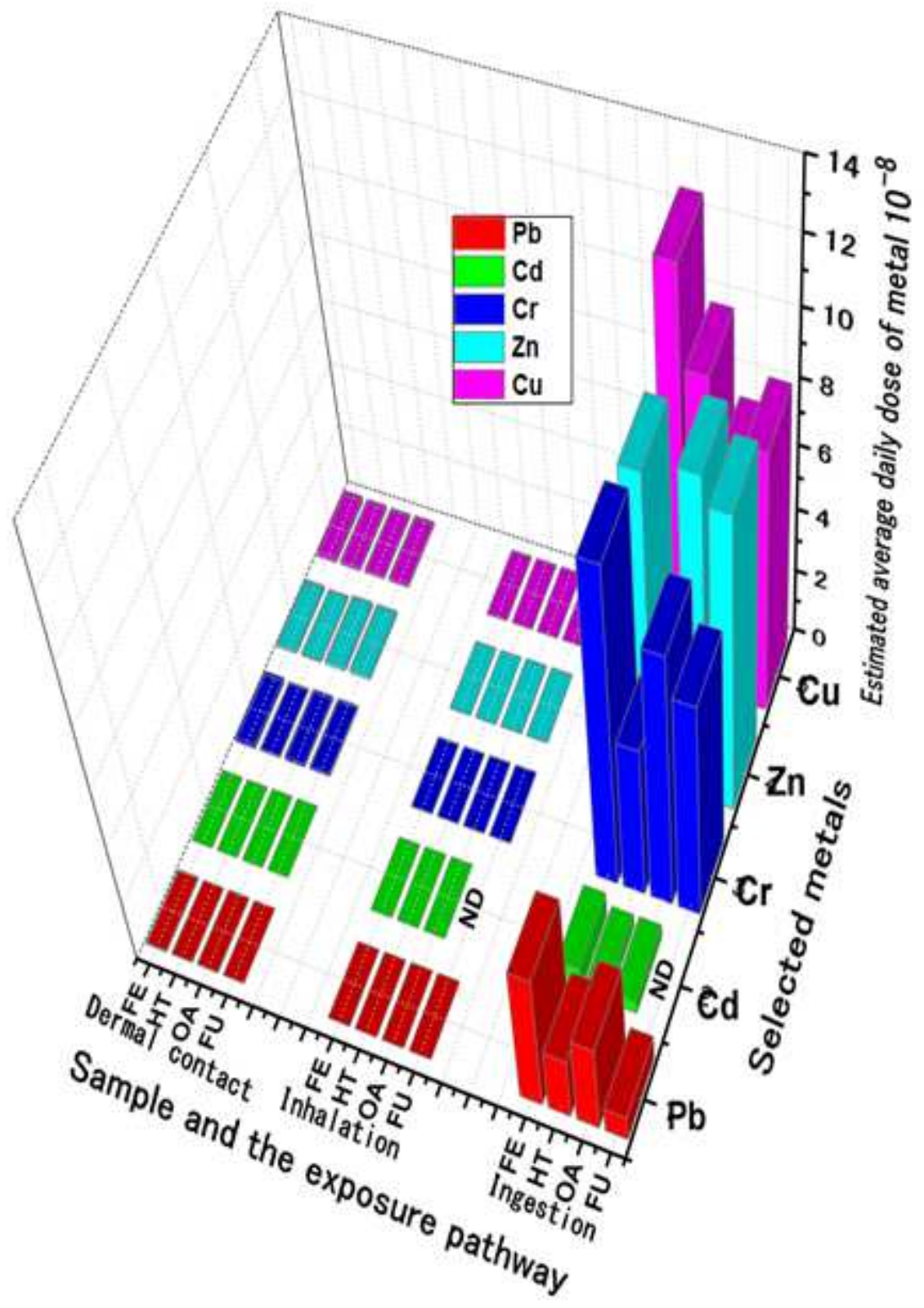

Figure 1

Estimated average daily dose of heavy metals in the dust samples Note: ND denoted not detected Location of sample: FU: Federal University of Technology, Akure; FE: Federal College of Agriculture; HT: Ondo State College of Health Science Technology; OA:Adeyemi College of Education 